Article

\title{
Festivals for Inclusion? Examining the Politics of Cultural Events in Northern Cyprus
}

\author{
Rahme Sadikoglu \\ Sociology Department, Goldsmiths College, UK; E-Mail: rsadi033@alumni.gold.ac.uk
}

Submitted: 14 April 2021 | Accepted: 16 August 2021 | Published: 30 November 2021

\begin{abstract}
In Northern Cyprus, cultural festivals are increasingly popular. The routinely celebrated festivals transform small villages into colourful celebrations with lots of activities and great culinary experiences, offering opportunities for social contact between members of different generations. People meet in the streets, where traditional food and handicrafts are on display and traditional folk dance performances usually take place. Cultural events provide an important space in which older generations often nostalgically remember the past with others of their generation and share their memories with the young people. Bi-communal interactions between Turkish Cypriots and Greek Cypriots in these public spaces also help leave behind and bury the violence of the past, nationalistic dogma, and intolerance. Drawing on ideas from postcolonial theory, cultural studies, sociology, and scholarship on public art, this article develops a post-postcolonial approach to explore the politics and value of Turkish Cypriot cultural festivals and the ways in which Turkish Cypriots are bridging differences with Greek Cypriots. Through observations, conversations, and interviews conducted with Turkish Cypriots from June 2014 to October 2017, the article also discusses the ways in which public art encourages dialogue and multicultural tolerance in Cyprus. The article argues that the rise of interest in Turkish Cypriot folk arts and multicultural tolerance, as propagated by Turkish Cypriots, should be understood in more complex terms than simply that of positive inclusion, as an ambivalence closely connected to the East/West division. Accordingly, the article illustrates that the coexistence of inclusion and exclusion are at the heart of Turkish Cypriot society.
\end{abstract}

\section{Keywords}

Cypriotness; cultural festivals; identity politics; inclusion; Northern Cyprus; Orientalism; post-postcolonialism; public art

\section{Issue}

This article is part of the issue "Art and Design for Social Inclusion in the Public Sphere" edited by Karin Hannes (KU Leuven, Belgium).

(C) 2021 by the author; licensee Cogitatio (Lisbon, Portugal). This article is licensed under a Creative Commons Attribution 4.0 International License (CC BY).

\section{Introduction}

The geographical position of Cyprus, which stands at the crossroads of Europe, Asia, and Africa, has long been politically important. Due to its strategic value, the island has attracted many of the world's great civilisations starting from the 8th millennium BC. More recently, Cyprus was part of the British Empire from 1878 to 1960. During the colonial era, inhabitants of Cyprus identified themselves as belonging to Greece and Turkey, because of their belief that their ancestors had originated from those countries. As Loizides (2007, p. 174) writes, Greek Cypriots "saw their destinies as linked to the ancient Hellenic past of Cyprus and their future to its revival through unification with Greece." Similarly, Kizilyurek (2002, p. 75) argues that the rise of an independent Greek state after the 1821 Greek War of Independence was a turning point in Cyprus's history, and that it led to the emergence of ethnonationalist consciousness among the Orthodox Christians of Cyprus. The development of nationalism among Turkish Cypriots, on the other hand, was partly fostered by "fears of marginalization" (Loizides, 2007, p. 174) and Turkish Cypriots' anxiety at the prospect of becoming a minority in a state incorporated into Greece. The move towards nationalism was also encouraged by the establishment of the Republic of Turkey in 1923, and by the Kemalist movement in Turkey (Nevzat, 2005). 
British colonial policies and practices also made significant contributions to the growth of Turkish and Greek nationalisms in Cyprus. The impact of the colonial influence was such that the Cyprus that emerged after the first effects of colonialism were felt was markedly different from precolonial Cyprus. Instead of being referred to as the Muslims (Nevzat, 2005) and Orthodox Christians of Cyprus, the people of Cyprus began to be identified as the Turks and Greeks of the island. Furthermore, each community was determined to fight for its own distinct nationalist goals. Despite the foundation of the new Republic of Cyprus, intercommunal conflict began in 1963. The communities who were psychologically divided under the new federation would soon become physically and demographically divided too.

The island became separated in two following the Turkish invasion of the island (a response to the Greek coup that took place in 1974). The United Nations buffer zone, known as the Green Line, was established in 1974, dividing Cyprus and separating the two communities. Greek Cypriots now reside in Southern Cyprus, in the legally recognised Republic of Cyprus; Turkish Cypriots reside in the north, in an unrecognised, self-declared state called the Turkish Republic of Northern Cyprus (TRNC). There have been many diplomatic attempts by both domestic and international parties to improve peace and harmony in Cyprus since the onset of the issue. For the past 47 years, numerous negotiations and peace talks have started, stopped, been fast-tracked, and revisited. Nevertheless, nearly five decades after the division of the island, it is still imperative to find a comprehensive solution to the Cyprus conflict.

Studies of nationalism and identity in Northern Cyprus have focused on adaptations of ethnic nationalism under British rule (Kizilyurek, 1999, 2002; Loizides, 2007; Pollis, 1996, 1998) and "identity fluctuations" in the Turkish Cypriot community after the division of the island in 1974 (Lacher \& Kaymak, 2005; Navaro-Yashin, 2006; Vural \& Rustemli, 2006). These studies have demonstrated that since the division of Cyprus, ethnic nationalism (Turkishness) in the Turkish Cypriot community has been in decline, and a civic notion of identity (Cypriotness) has gained ascendancy. Scholars have analysed the resurgence of Cypriotness in Turkish Cypriot society and its relationship with the recent political, socio-economic, and cultural shifts in Northern Cyprus (Hatay \& Bryant, 2008; Kizilyurek, 2018; Navaro-Yashin, 2006). What is lacking in such discussions is a consideration of the ways in which cultural practices, such as the repeated cultural festivals, serve to represent and reinforce the cultural and political underpinnings of Turkish Cypriot identity. As Hall (2007, p. 152) argues, in order to understand "how difference operates inside people's heads, you have to go to art, you have to go to cultureto where people imagine, where they fantasise, where they symbolise."

Following Hall's argument, this article attends to Turkish Cypriot cultural festivals to add a valuable contri- bution to areas of the debate that have been largely unexplored, such as the production of cultural distinctions and similarities through cultural practices. To expound further, drawing on ideas from postcolonial theory, sociology, cultural studies, and scholarship on public art, this research contributes to areas of the debate by developing a post-postcolonial analytic as a mode of exploring the value and politics of Turkish Cypriot cultural festivals and the notion of Cypriotness. It becomes evident that this original approach/concept opens room to further understand the fragmentation and paradoxes of postpostcolonial narratives produced by Turkish Cypriots and the multitude of political and cultural factors that lay the foundation for the formation of contemporary Turkish Cypriot identity.

Without a doubt, this article also draws from the scholarship on public art. Indeed, this research characterises Turkish Cypriot cultural festivals and practicessuch as the display of traditional buhurdanlik, sestas, words, and even folk dance performances-as a form of public art. Accordingly, it pays attention to postpostcolonial narratives and dialogues that surround public art, and discusses how public art is received within the post-postcolonial public sphere. This discussion testifies to the value of Turkish Cypriot cultural festivals, revealing how public art can generate dialogue and encourage multicultural tolerance among the communities of Cyprus.

\subsection{Defining Post-Postcolonialism and Post-Postcolonial Discourse}

Since the partition of the island in 1974, Turkish Cypriots have been living in an unrecognised state. They have the last divided capital city in the world (Nicosia), and they lack the capacity to participate autonomously in European Union arrangements for Cyprus. This has caused physical, social, and psychological problems for Turkish Cypriots, who have been secluded from the world (Sadikoglu, 2019). Additionally, the cultural and economic embargoes imposed on the Turkish Cypriot community since the declaration of the TRNC in 1982 have created a relentless and restrictive dependence on Turkey, both politically and economically. Indeed, Aydın (2006, p. 226) suggests that the TRNC would not survive even a day without Turkey's heavy tutelage.

Moreover, the post-war period and the division of the island brought about cultural, economic, political, and social transformations in Northern Cyprus. Since the Justice and Development Party (AKP) came to power in Turkey in 2004, it has followed a strategy of progress for Northern Cyprus that encompasses the construction of four-lane highways, religious learning establishments, beachfront hotels and mosques, and recently an undersea pipeline from Anatolia. The increasing Turkish population, on the other hand, added a new aspect to the population ratios, changing the demographic challenge on the island. These political, social, economic, and cultural circumstances have given rise to the discourse in Turkish 
Cypriot community that the Turkish Cypriot population is "shrinking" (see Hatay, 2007) and that Turkish Cypriots are losing their Cypriotness as Northern Cyprus is becoming like Turkey. The present study, however, is not concerned only with the economic, political, and social relationships with Turkey that have existed in Northern Cyprus since 1974. It also looks at another interesting epoch, which I will refer to as post-postcolonialism.

Post-postcolonialism is about the conjuncture of the residues of British colonialism in Northern Cyprus and the consequences of the complex relations with Turkey. As Hall and Massey (2010, p. 57) note, a conjuncture "is a period during which the different social, political, economic and ideological contradictions that are at work in society come together to give it a specific and distinctive shape." A conjuncture, Hall and Massey (2010, p. 57) suggest, "is not defined by time or by simple things like a change of regime"; rather, it is an intricate historical point where forces meet and lead to drastic change. Following on from this, I argue that Cypriotness, or the value and politics of Turkish Cypriot cultural festivals, can be fully explained neither with reference to the recent social, political, cultural, and economic transformations in Northern Cyprus, nor in relation to British colonialism. Each without the other would provide only a partial elucidation of the notion of Cypriotness and its manifestations. Thus, a conjunctural perspective informs my approach to analysing the notion of Cypriotness and Turkish Cypriot cultural festivals.

\subsection{Orientalism and Post-Postcolonial Discourse}

My analysis of the relationship between the notion of Cypriotness and Turkish Cypriot cultural festivals is based on what I call post-postcolonial discourse or the discourse of Cypriotness-these terms will be used interchangeably. It is this discourse that surrounds Turkish Cypriot cultural festivals. Post-postcolonial discourse is produced by indigenous Turkish Cypriots, and it is underpinned by a highly critical approach towards the nationalistic discourse that considers the relationship between the TRNC and Turkey to be one of "flesh and fingernail" (Bryant \& Yakinthou, 2012, p. 16). It is produced against two distinct constitutive "Others," namely mainland Turks and Greek Cypriots, where mainland Turks are constantly judged for their "Oriental" behaviour (Said, 1978/2006) and Greek Cypriots are praised for their "Europeanness." However, as Mbembe (2008, para. 12) states, postcolonial thinking is about "the recognition of the Other as fundamentally human," which for him is "all too often forgotten." In line with this notion, this article explores and challenges the fairness, unfairness, falsity or validity of claims constructed by post-postcolonial discourse. It is for this purpose that I engage with Said's (1978/2006) notion of Orientalism.

I am aware that Said developed his analysis from literary texts. Therefore, his ideas may not translate into the living of complicated axes of difference in contempo- rary contexts. The case of Cyprus thus offers an interesting example from which to further develop postcolonial analysis. In this study, I develop two central arguments that Said first provided in Orientalism (1978/2006). First, I engage with Said's argument that Orientalism is a way or style of thought that pivoted on contrasting the Orient (the East) with the Occident (the West, or Europe). I engage with the idea that Orientalism generates a view of the Orient that is also a moral structure within which the Orient is criticised, even punished, for not conforming to the strictures of the European community, thus Orientalising the Orient (Said, 1978/2006, p. 67). However, I apply this line of thinking to the specific context of Northern Cyprus in order to discuss a different kind of Eurocentric discourse-I focus on a discourse that is post-postcolonial and belongs to Orientalism.

Second, following on from Said (1978/2006), I will suggest that the portrayal of mainland Turks as Eastern and Oriental by my research participants is a representation which allows mainland Turks to be spoken of from a position of "power," not "truth" (Said, 1978/2006, p. 21). It is a position of power because indigenous Turkish Cypriots consider themselves superior to the Eastern Other by virtue of their assumed proximity to Western culture. Yet, I will argue that post-postcolonial discourse, which observes the Orient from "above" (see Said, 1978/2006, pp. 333-334), is produced from a position not only of power, but also of powerlessnessbecause when the other Other (Greek Cypriots) enter the picture, Turkish Cypriots' feeling of superiority and power is challenged. Thus, taking Said's Orientalism as a starting point, this research develops postcolonial analysis by illustrating that Orientalist discourse in contemporary Turkish Cypriot society observes and constructs its subjects from a position of in-betweenness: a position of simultaneous power and powerlessness.

\section{Methodology}

In empirical terms, the main data of this ethnographic research were generated through participant observation (over 40 months, from June 2014 to October 2017), semi-structured interviews, and informal/conversational interviews.

\subsection{Participant Observation}

Observation locations were at cultural festivals in two different locations: Mehmetcik and Buyukkonuk. I conducted four hours of participant observation at the Eco Day Festival in Buyukkonuk (a village in the Famagusta district) in October 2016, and 40 hours of participant observation at the Grape Festival in Mehmetcik (another village in the Famagusta district) in August 2016.

I started the fieldwork with descriptive observations of the field sites. I subsequently followed up these descriptive tours with more focused and selective observations. My overarching aim was to gain a 
sense of the following: (a) activities and practices carried out in their social settings; (b) various forms of expressive culture, such as music, dance, song and art; and (c) more specifically, social interactions and conversations between Turkish Cypriots and mainland Turks, Turkish Cypriots and Greek Cypriots, and among Turkish Cypriots themselves. Participant observation enabled me to observe interactions among the communities of Cyprus (Turkish Cypriots, mainland Turks, and Greek Cypriots) and to grasp how they communicated with each other. Additionally, participant observation allowed me to examine subjects' everyday lives and cultural practices from their point of view, as well as to observe situations that subjects might otherwise have been unwilling to share. The importance of these interactions is underscored by how they enabled me to contextualise the engendering/formulation of cultural distinctions and cultural similarities between Turkish Cypriots, mainland Turks, and Greek Cypriots.

\subsection{Semi-structured and Informal Interviews}

Besides observing the field sites, I conducted semistructured and informal interviews (conversations) with indigenous Turkish Cypriots during my fieldwork. Semistructured interviews and informal interviews with the participants helped me to complement my observations and to understand the complexity and ambivalence of their narratives, as well as the tensions and negotiations among Turkish Cypriots, mainland Turks, and Greek Cypriots. Informal interviews constituted one of the most significant and valuable of my data sources. For the most part, informal interviews took place in Northern Cyprus between June 2014 and October 2017. Although the informal interviews were unstructured, they helped me to identify participant-centred concerns and experiences that informed the semi-structured interview questions.

I conducted a total of 27 semi-structured interviews in different cities in Northern Cyprus with men and women with a mix of ages. As I discuss in the next section, the vast majority of my participants were post-war generation Turkish Cypriots. The participants selected during the fieldwork were recruited using a combination of convenience sampling and snowball sampling techniques (see Bryman, 2016, pp. 187-188). One of the epistemological advantages of using semi-structured interviews was that they provided me with a rich plethora of information through the use of open-ended questions. This open-ended approach also enabled my interviewees to talk freely about the issue, and in turn, offered an "insider view of the social world" (Bazeley, 2013, p. 27) and provided "compelling descriptions of the qualitative world" (Kvale \& Brinkmann, 2009, p. 48).

The research involved "sensitive topics" (see Lee, 1993). Therefore, it was imperative that I carefully consider the wording of interview questions, the selection of participants, and the ethical framing of the research regarding communicating the confidentiality and anonymity of the data.

\subsection{Representativeness of the Participants}

It is important to note that I was drawn to this project by my own personal struggles in negotiating my identity as a young-generation Turkish Cypriot, and by the struggles of other young Turkish Cypriots that came to my attention during my observations in Cyprus and London. Therefore, my research focuses on a particular generational experience. In this study, I explore the views and experiences of a specific generation of Turkish Cypriots with certain socio-political and ethnic characteristics. Most of my participants are post-war generation Turkish Cypriots who have no direct experience of pre1974 Cyprus. Consequently, this might mean that their political views are likely to be at odds with those of the older generation who experienced the war and intercommunal violence (although that is not within the scope of this article). The majority of the participants' political affiliations are aligned with left-wing parties such as Akinci and are opposed to the policies of ethnonational parties (such as UBP and DP). Like me, all of them had completed their primary and secondary school education in Cyprus. The majority had studied in universities in Cyprus, while some had studied in universities in the UK like me, or in universities in Turkey.

Lastly, all my participants are indigenous or native to Cyprus. Accordingly, in this article, I use the term "Turkish Cypriots" to refer to my research participants who are post-war generation Turkish Cypriots and whose ancestors settled in Cyprus after 1571. The term "mainland Turks," on the other hand, refers to all Turks who migrated to Northern Cyprus in the last few years. I found that my participants tend to be more critical of this group of people. My term "mainland Turks," in this sense, does not include children of mixed marriages, children of mainland Turks that were born and raised in Cyprus, and Turkish people from Turkey that settled in Northern Cyprus between the 1970s and 90s and became dual citizens.

\section{Cultural Festivals in Northern Cyprus}

In recent years there has been a surge of interest in Turkish Cypriot cultural festivals, with indigenous Turkish Cypriots exploring their intangible cultural heritage of food, songs, dances, stories, language, and cultural practices. Buyukkonuk Eco Day Festival and Mehmetcik Grape Festival, for instance, are among the most popular of these events. Buyukkonuk Eco Day Festival promotes traditional Cypriot customs, dishes, and specialties twice a year in May and October. Mehmetcik Grape Festival, on the other hand, promotes viticulture by bringing the cultural importance of the grapes and vineyards of the Karpas Peninsula to the fore every year in August. Each cultural event, in this sense, focuses on 
a particular aspect or region of the island, promoting and preserving the unique history and culture of Cyprus, raising awareness of local traditions, and boosting local economy. My research, however, reveals that Turkish Cypriot cultural festivals have at least one other significance: They reflect a struggle between two opposing discourses-official or nationalistic discourse and the discourse of Cypriotness or post-postcolonial discoursewithin the geopolitical formation of Northern Cyprus.

Many theorists in the studies of public art argue that a work of art is public when its reception takes place within the public sphere (Baldini, 2014; Knight, 2008; Zuidervaart, 2011). In Habermas' view (1989), the public sphere is a discursive space formed by members of the public who are interested in carrying out discussions related to the public interest. As Baldini (2014, pp. 18-19) writes, the public sphere "is not influenced by public authority"; its debates are "a form of political action [that] aim at shaping decisions of public authority on particular issues." Accordingly, I follow this dominant trend in the studies of public art and argue that Turkish Cypriot cultural festivals function as social spaces, or as a public sphere, where members of the public discuss political, social, cultural and economic issues related to their needs and interests. These discussions generally reflect a resistance against official discourse. In this regard, I characterise Turkish Cypriot cultural festivals as a form of public art.

After the division of the island in 1974, official or nationalist discourse constructed a hegemonic form of thinking by promoting an idea of sameness and solidarity between Turkish Cypriots and mainland Turks, and an idea of separation between Turkish Cypriots and Greek Cypriots (see Papadakis, 2008). Cypriotness or Cypriotism, on the other hand, has emerged as a cultural resistance to official (nationalist) discourse. Cypriotness is a new discourse and a new hegemonic and cultural movement or formation that is founded on an idea of oneness and shared culture between the Greek Cypriots and indigenous Turkish Cypriots. This new movement also revolves around the idea of difference between mainland Turks and indigenous Turkish Cypriots. As my findings below suggest, the notion of a resurgent Cypriotness is not defined as merely aspiring to overcome the hegemony and authority of ethnonationalist knowledge production-such as the nationalist themes and essentialist identities produced by the state-but rather aims to transform values, structures, and social relations in such a way that reconciliation can be achieved with those (Greek Cypriots) who have been considered Other.

My empirical data elucidates that Turkish Cypriot cultural festivals are interlinked with the discourse of Cypriotness. They are, in Foucault's terms, part of the same "discursive formation" (Hall, 1997, p. 44), meaning that they support a common strategy. Accordingly, I found that Turkish Cypriot cultural festivals have at least two other functions: (a) to remake and produce cultural distinctions between the Self (Turkish Cypriots) and mainland Turks and (b) to close the gap between the Self and Greek Cypriots. These events, in this sense, engender dynamics of inclusion, exclusion and resistance as means of overcoming the difficulties associated with the sense of in-betweenness - a collective positioningto which post-postcolonial condition gave birth.

\subsection{Collective Positioning}

A significant impact of British colonialism in Cyprus was that it gave rise to split subjects, leaving Turkish Cypriots with a hybrid culture. Many elements are involved in the hybrid culture of Turkish Cypriots. Turkish Cypriot culture is influenced by the English civilisation of the British colonial era and Kemalist reforms (Nevzat, 2005) and also coalesces these elements with local traditions that are shared with Greek Cypriots. Whether through the adaptation of Kemalism (see Hatay, 2009) or of the colonisers' cultural habits, attitudes, and values, the colonial period in Cyprus gave rise to "something different, something new and unrecognisable" (Rutherford, 1990, p. 211), turning the Muslim Turks of the island into what are today seen as liberal Turkish Cypriots (Smith, 2018). What it means to be a Turkish Cypriot in Cyprus today thus lies at a complex intersection of Eastern and Western cultures.

Turkish Cypriot identity, like all identities, is "fragmented and fractured" (Hall, 1996, p. 4), but it specifically incorporates at least two cultural "presences" (Hall, 1990, p. 230): the presence of Turkishness and the presence of Cypriotness. The presence of Cypriotness signifies power, inclusion, and exclusion. It "provides a sense of rightful temerity to the advance of modernity by virtue of its historical affiliation with British civilisation" (Beyazoglu, 2017, p. 216). The sense of Cypriotness, in this regard, leveraged greater power to criticise, judge or exclude mainland Turks who are considered to be inferior and different. The presence of Turkishness, on the other hand, can also imbue Turkish Cypriots with a subjective sense of inferiority and backwardness due to their encounters with Greek Cypriots (see below). Accordingly, my findings suggest that rather than producing an equal hybridisation of cultures, my participants develop counterhegemonic strategies that rely on essentialised notions of Cypriotness supposedly shared by indigenous Turkish Cypriots and Greek Cypriots. Interestingly, during British colonialism, Turkish Cypriots' approach to mainland Turks or Greek Cypriots was not marked by a belief in the binary of "superior Cypriotness" versus "inferior Turkishness." That is to say, Turkish Cypriots did not bring with them any ready-made ideas of "Turkish inferiority," "Cypriot superiority" or an exalted Cypriotness shared by both Turkish Cypriots and Greek Cypriots. I therefore argue that there is one event that we need to pay close attention to here: the opening of the Green Line on 23 April 2003.

The opening of the Green Line made significant changes to Cypriots' lives-both Greek Cypriots and Turkish Cypriots. People from both communities flocked 
to the other side to see their abandoned homes, visit family graves and meet friends they had not seen since the division of 1974. This was the first time that young Cypriots came together with the Other community. After their first crossings, Turkish Cypriots encountered boutiques selling global brands and shops providing electronics and alternative consumer products that they could not find in the North (Hatay, 2009). Significantly, in the historic moment of crossing the border and meeting Greek Cypriots, Turkish Cypriots were confronted with the reality that standards of living and material resources on the Greek side of Cyprus were seemingly superior in comparison to Northern Cyprus. In the same moment, they seemingly were hit hard by the reality that they were not as European or Western as they thought.

Accordingly, my findings suggest that although indigenous Turkish Cypriots tend to position themselves as superior to the mainland Turks through their association with a sense of Cypriotness, their encounters with Greek Cypriots call this sense of superiority into question. The moment Greek Cypriots enter into the equation, this sense of superiority is challenged. The feeling of superiority is replaced by collective feelings of distress, inadequacy and powerlessness every time an indigenous Turkish Cypriot, for instance, crosses the border and realises that the island's other half (the Greek Cypriot side) appears more progressive, more European and more modern than the Northern side. These feelings are also reinforced by the cultural racism that they encounter in everyday life when a Greek Cypriot person reduces Turkish Cypriots to their Turkishness, as backward and lacking (see Sadikoglu, 2019). This is where a new binary opposition-between superior Greek Cypriots and inferior indigenous Turkish Cypriotsarises, and the complexity of identity in Northern Cyprus goes beyond the binary opposition of superior Turkish Cypriots and inferior mainland Turks. Relatedly, my research reveals that it is from this post-postcolonial space or position in between two binary oppositions that there emerges a new identity, which I refer to as "not so Eastern, not so European: something in-between."

Turkish Cypriot cultural festivals-as well as the discourse of Cypriotness that surrounds these events-are closely related to this imaginary in-between position. Turkish Cypriots decipher their lived reality through this position, which is passed down from generation to generation. It is from this stance that they determine the parameters between "us" and "them"; and the subsequent illusionary position from which mainland Turks and Greek Cypriots are seen. More specifically, it is this imaginary stance that produces mainland Turks as deficient, backward, and a threat to Turkish Cypriots' culture, and Greek Cypriots as more Western, European, and modern. In this sense, as the examples below illuminate, this position underpins the "interconnection between 'happy' and 'hard' forms of coexistence" (Wise \& Velayutham, 2014, p. 406), or between conviviality and various forms of cultural racism in Northern Cyprus.

\subsection{Exploring Practices and Instances of Inclusion}

Bi-annually, in May and October, Buyukkonuk village turns into a bustling marketplace. Villagers keep themselves busy by preparing the homemade products in which they take such pride and sell and share them at Buyukkonuk Eco Day Festival. Many traditional foodstuffs, such as Cypriot hellim cheese, zeytinli, and hellimli (olive and hellim bread), lokma and harnup pekmez (carob molasses), are on display, along with traditional handicrafts and folk dancing. The festival lasts from dawn to dusk, and the small village becomes a vibrant centre for celebration. I attended the festival in October 2016 for the purposes of this research. At the entrance to the festival area, I see a huge traditional buhurdanlik (Figure 1). The buhurdanlik occupies an important place in Cypriot culture. Both Turkish and Greek Cypriots use it: They burn olive branches in it, and then turn the branches three times above their heads. According to tradition, the smoke will safeguard the home and family from evil spirits.

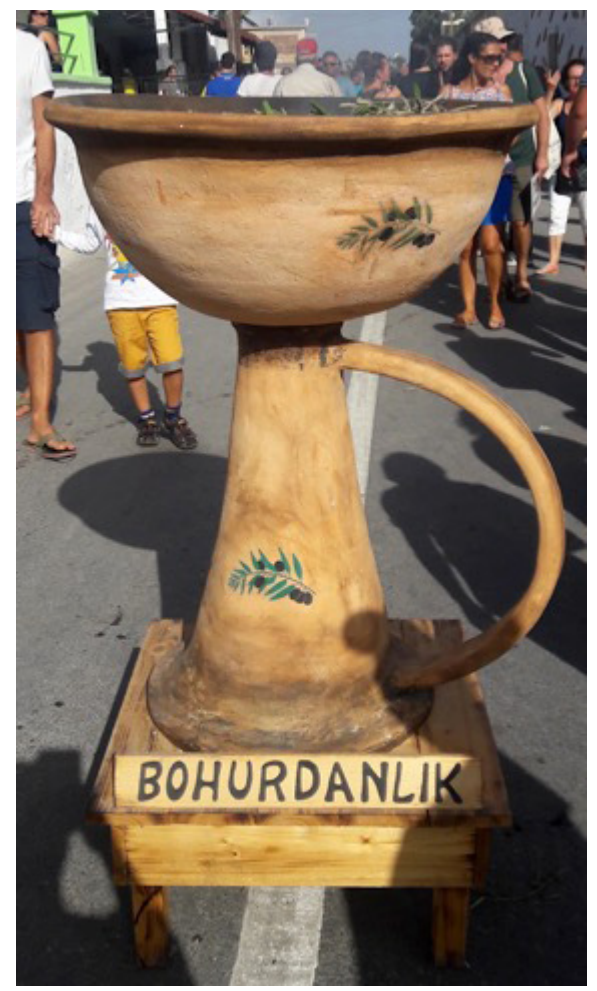

Figure 1. Buhurdanlik. Photograph by the author.

There is a stall where sestas are on display (see Figure 2). Sestas are everyday traditional objects which Greek and Turkish Cypriots serve and eat food from. Thus, like the buhurdanlik, sestas embody the cultural artefacts and practices that Greek and Turkish Cypriots share. While sestas were used more commonly in the past, today they are also used locally for decoration purposes.

There is also a display of words on a house wall (see Figure 3). Language is a marker of cultural hybridisation in Turkish Cypriot society. The words displayed on the 


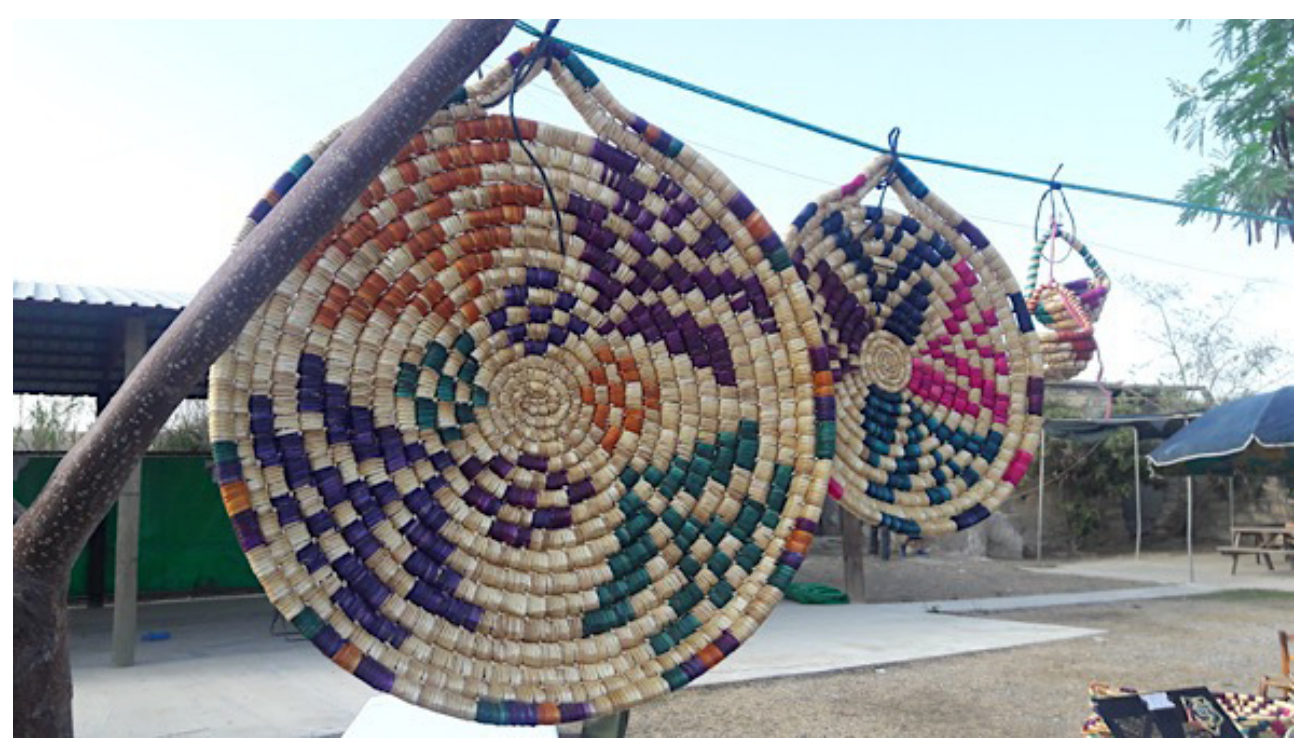

Figure 2. Traditional sestas. Photograph by the author.

wall, which include piron (fork), potin (shoes), iskemle (chair), gabira (toasted bread), ispaho (yarn), belesbit (bicycle), lagani (waterway), and bavuri (tin water bottle) are in the Turkish Cypriot dialect; they are not used in standard Turkish. Thus, they serve to represent a symbolic distinction from mainland Turks. Some of these words also represent the linguistic similarities between the Turkish Cypriot and Greek Cypriot dialects. According to Hadjipieris and Kabatas (2017), piron, gabira, and bavuri are among the 3,500 common words used by Greek Cypriots and Turkish Cypriots. Kabatas (as cited in "Bilingual dictionary reflects Cypriots' common words," 2016) states that, "while the mother languages, modern Greek and Turkish, move in parallel and they do not meet, the local dialects, Greek Cypriot and Turkish Cypriot, intercept each other and this is attributed to the elements comprising their common cultural tradition."
A large number of words shared between the two dialects are no longer used by Turkish and Greek Cypriots. Nevertheless, these words-like the smell and taste of foodstuffs-are laden with "broader cultural associations" (Rhys-Taylor, 2013, p. 237), and the meanings people attach to them are active in making and remaking cultural similarities and distinctions. The words displayed on the wall at the festival signify and highlight that Greek and Turkish Cypriots shared similar ways of life when they lived together. They may even evoke memories. Each separate word is a representation of memories, a common story, a common place, and a joint experience. Each word is also a marker of difference between mainland Turks and Turkish Cypriots. As Bourdieu (as cited in Swartz, 1997, p. 6) would argue, practices such as the display of the buhurdanlik, the sestas, and the words "embody interests" and function to enhance cultural

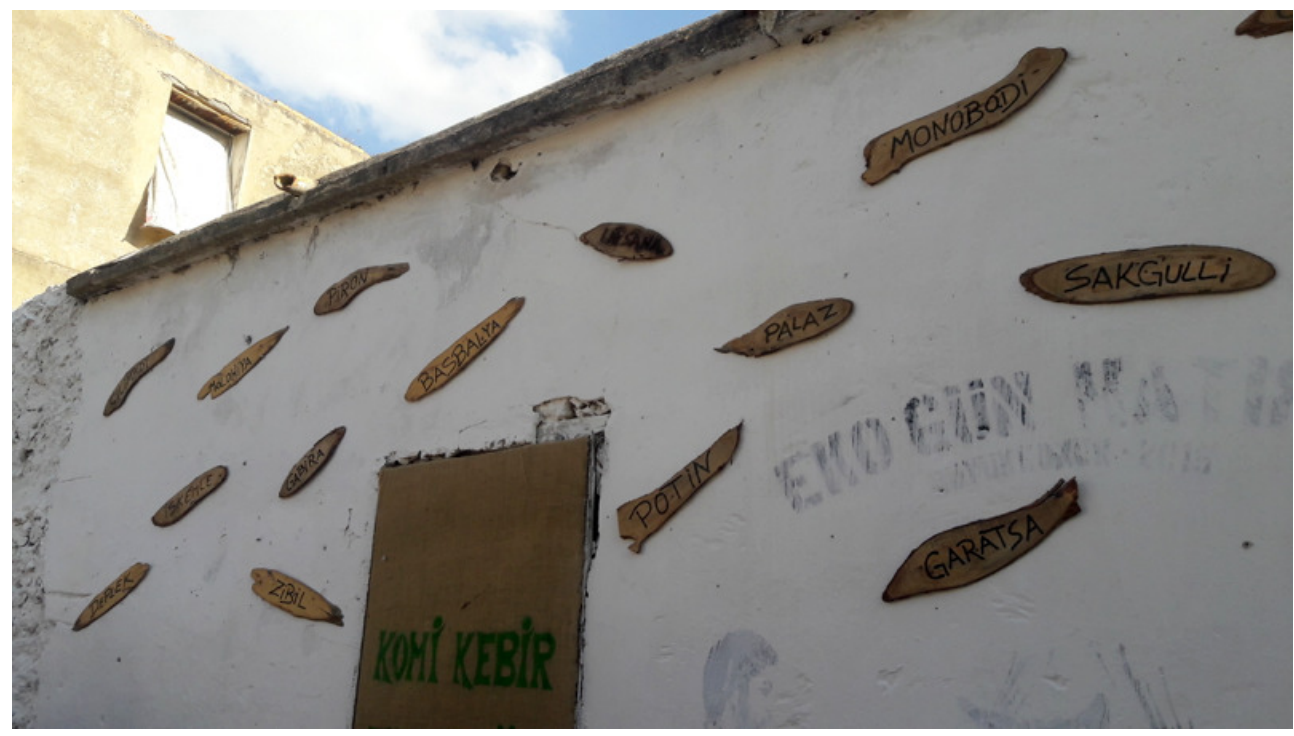

Figure 3. Words used by Turkish Cypriots in Turkish Cypriot dialect, displayed on a wall. Photograph by the author. 
similarities and distinctions. Each practice or symbolic work serves to form an identity (Bourdieu, 1984, p. 56) by erecting symbolic boundaries between people who occupy different locations in the cultural structure.

Relatedly, although the buhurdanlik, the sestas, and the words on display seem to be just traditional objects in a public space, I suggest that these objects can be classified as public artworks as they are "received within the public sphere" (Baldini, 2014, p. 19). By engaging these objects, Turkish Cypriots do not simply attend to the artistic or aesthetic features of these artworks. Instead, they are encouraged to respond to the presentation of these public artworks by discussing current political, cultural, and socio-economic issues in Cyprus. These dialogues take place within the boundaries of a specific type of public sphere and are based on a specific type of discourse, which I have called post-postcolonial. In this regard, as many theorists would suggest, public art encourages dialogue (Finkelpearl, 2013; Kester, 2011; Lacy, 1995), and this is the case in Northern Cyprus. Indeed, my findings reveal that Turkish Cypriot cultural festivals encourage dialogue between Turkish Cypriots and Greek Cypriots, and among Turkish Cypriots themselves that are aiming at challenging the nationalist discourse.

An instance of how Turkish Cypriot cultural festivals, as a form of public art, encourage maximally inclusive dialogue, tolerance, and coexistence can be found in the following example. Towards the end of the festival, I come across a bi-communal dance show performed by folk dancers from both communities in the main festival area. A member of this bi-communal folk dance association states that the folk dance performance aims to unite Greek Cypriots and Turkish Cypriots to embrace their common culture and bring lasting peace to the island. After the performance, I see a Turkish Cypriot family (father, mother, daughter, and son) standing next to me. The children are post-war-generation Turkish Cypriots who were born after the division of the island; by bringing them to cultural festivals, the father and mother (both from the war generation) can weave their memories into direct conversations with their children, in an effort to transpose the cultural history of Cyprus and of life before the island was divided. The father is telling his children about the communities' peaceful coexistence before the division of the island. He articulates that if wider factors and forces did not "brainwash" people, then the two communities would live in peace. The father and mother also talk about how similar the Self (Turkish Cypriots) is to the Greek Cypriot Other or vice versa. This is a significant contrast to the killing and maiming described in history books (see Vural \& Özuyanık, 2008) and family stories about traumatic events (see Sadikoglu, 2019), with a new shift to the "warm" and "loving" nature of both Turkish Cypriots and Greek Cypriots.

As my data suggest, these narratives are also common in everyday life. Indeed, I found that the vast majority of my participants attributed Greek Cypriot or Turkish Cypriot hatred to structural factors and state agencies.
This seems to suggest that much of the hatred has been subsumed, worked through or repressed. Moreover, the vast majority of my participants often claimed a common Cypriot identity "that recognises the many points of similarity" (Hall, 1990, p. 225) on the one hand and masks differences on the other. The participants did not wish to discuss the cultural differences that exist between the two communities at all, or they relegated differences to the realm of language and religion. It is inevitable that cultural festivals encourage the communities of Cyprus to confront their differences through social interactions and develop more tolerant behaviours. Yet, the reasons behind the transition from an exclusionary past to an inclusionary present are also significant and need to be addressed here.

My research elucidates that the inclusion of Greek Cypriots is closely related to specific interests regarding cultural supremacy and the socially constructed positions that Turkish Cypriots adopt in relation to Greek Cypriots. As I discussed earlier, after the opening of the Green Line in 2003, there emerged different cultural categories/hierarchies into which people are divided. At the top of the cultural hierarchy are the Greek Cypriots, who assumedly (unlike Turkish Cypriots) are able to preserve their cultural values-their Cypriotness-which are associated with Westernness/ Europeanness. At the bottom of the cultural hierarchy are mainland Turks, who arrived on Northern Cyprus in the last few years. This group, by Western "standards," is considered to be backward and inferior to both indigenous Turkish Cypriots and Greek Cypriots due to the idea that this group of people is always in low-skilled occupations such as manual labour. In turn, they are demonised and excluded by the vast majority of my participants because of their positioning as Oriental and inappropriate subjects who pose a threat to "superior" Cypriot culture. Finally, I found that my participants are situated in between these two groups.

Although my participants consider themselves more European/Western than mainland Turks, the materiality of how they see their physical environment in different parts of the island are sources of distress and can trigger feelings of inadequacy/inferiority when they position themselves in relation to Greek Cypriots. In attempting to deal with this sense of insecurity, my participants dwell on cultural similarities between Turkish Cypriots and Greek Cypriotness. This is a strategy they use to close the gap between themselves and the superior Other (i.e., Greek Cypriots) so that they can maintain their sense of Cypriotness, which is associated with being European and Western. My findings suggest that the instances of inclusion thus reflect my participants' struggle for cultural equality, which can be achieved through particular fabrications of Cypriotness.

Another important point that needs to be noted here is that what the participants believe to be the Greek Cypriots' image in relation to the Self, or vice versa, is socially constructed: Not only is it imaginary, but it is also 
based on a Eurocentric worldview of Orientalism that allows the West to be spoken of from a position of powerlessness, "not truth" Said (1978/2006, p. 21). The stereotypes produced by the discourse of Cypriotness, in this sense, reflect a desire to attain power and superiority or, as Bhabha (1983, p. 27) writes, "an originality which is... threatened by the differences of race, colour and culture." Accordingly, in the following section, I discuss that although the vast majority of my participants are observing mainland Turks from "above" (Said, 1978/2006, pp. 333-334) and from a position of power, in reality their imagining of mainland Turks as inferior and backward has to do with the sense of inferiority/powerlessness that they feel in relation to Greek Cypriots. This is the discourse that I have dubbed postpostcolonial that surrounds cultural festivals in contemporary Turkish Cypriot society.

\subsection{Exploring Instances of Post-Postcolonial Exclusion}

As with most cultural events in Northern Cyprus, Mehmetcik Grape Festival functions as a public space that is conductive to convivial encounters and cultural exchanges between the communities of Cyprus, transnational audiences (such as foreign tourists), and migrant communities (such as mainland Turks). As I have already mentioned, a popular view in public art scholarship says that public art encourages dialogue and tolerance. This can mean that dialogues and cross-cutting interactions embedded in the appreciation of public artworks have the power to stimulate increased consideration of different viewpoints and counterbalance tensions between communities. My empirical data, for instance, suggest that although there are instances of discrimination whereby people from the Greek Cypriot community discriminate against Turkish Cypriots (or conversely whereby people from the Turkish Cypriot community discriminate against Greek Cypriots), Turkish Cypriot cultural festivals and bi-communal practices encourage positive valuation of the Other. In a similar way, these cultural events also lead to the formation of convivial relationships between Turkish Cypriots and mainland Turks. It is, however, important to acknowledge that the positive social outcomes of these events can sometimes be overridden by the Eurocentric assumptions that underpin the discourse of Cypriotness.

As part of my field research, I attended Mehmetcik Grape Festival in August 2016. In the main festival area was a food stall where a middle-aged woman made and sold gozleme (see Figure 4). The woman wore a headscarf, which for Turkish Cypriots signalled that she was from the mainland. Every day, I visited the festival, bought some food, and sat at one of the tables near the gozleme stall. This was where I witnessed interesting conversations about this Turkish woman from the mainland who was selling Turkish gozleme at a Turkish Cypriot cultural festival. For example, I heard comments from Turkish Cypriots about the Turkish woman at the gozleme stall and her mainland Turk customers such as "it's full of Turkish everywhere," "seventy percent of the visitors who come to the festival are mainland Turks, you see fewer Cypriots," or "they go for the cheap [gozleme], we go for the expensive [kebab]." Such comments encapsulate that a cultural exchange between a (migrant or settler) Turkish woman and indigenous people provides markers through which migrant or settler groups' "cultural differences are identified" by local people, "often with negative consequences" (Rhys-Taylor, 2013, p. 394).

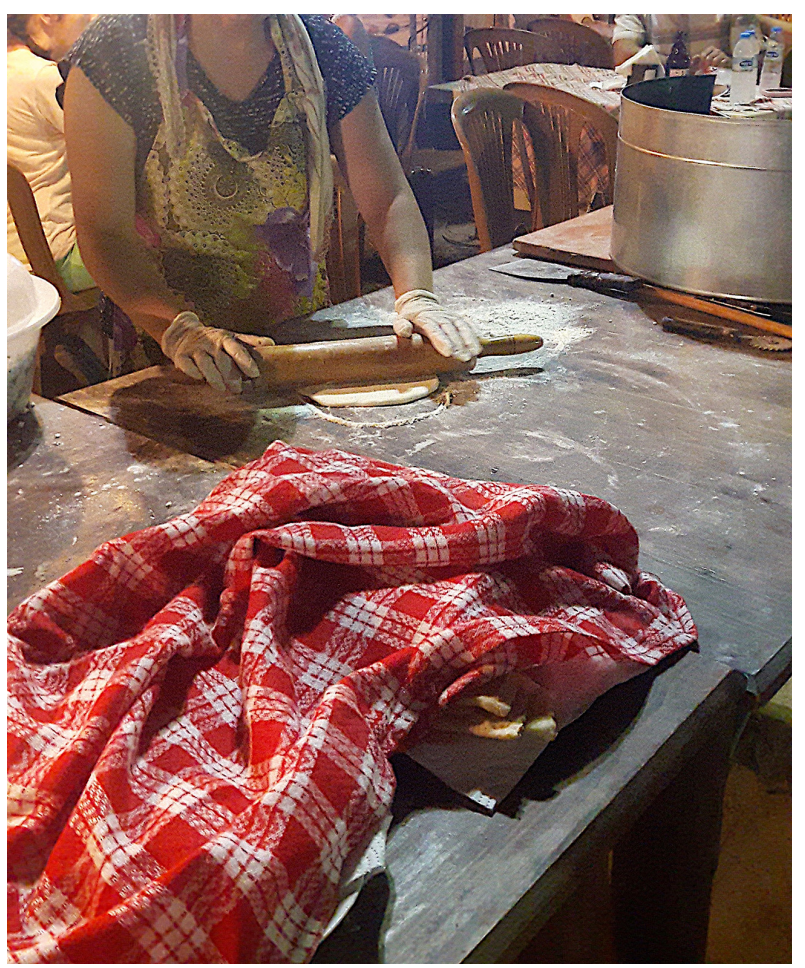

Figure 4. Turkish woman making gozleme. Photograph by the author.

Turkish Cypriots and mainland Turks have lived together in Northern Cyprus since 1974, sharing the island and myriad aspects of culture in their everyday lives. However, the distance between these two communities has gradually grown (Kizilyurek, 2018, p. 62). Indeed, in the interviews I conducted with my participants too, I observed a great deal of criticism aimed at mainland Turks, who arrived on Northern Cyprus in the last few years, in relation to their religion, gender roles, mentality, language, and everyday appearance. There was a tendency among the participants to undervalue and despise this group of people as inferior to the Self. In contrast, I found that Turkish Cypriots are more welcoming to mainland Turks who had settled on the island in the late 1970s, 1980s, and early 1990s. This group of people is considered to be relatively modern and well educated compared with mainland Turks who began to arrive on the island from the late 1990s onwards. Nevertheless, what my participants seemingly failed to recognise is that, as Said (1998/2005) once said, "we live in a very complex and mixed world in which you 
can't separate cultures and civilisations from each other." Indeed, "no one today is purely one thing" (Said, 1993, p. 336). The recognition that there is no pure Cypriotness that separates Turkish Cypriots from mainland Turks was nowhere to be found in the interviews I conducted with Turkish Cypriots.

I found that the designation of mainland Turks as inferior by my participants resonates with Said's (1978/2006) work on the ideology of Orientalism. In both instances, the Orient is juxtaposed with the Occident, forming a conceptual binary. What makes post-postcolonial discourse different and so original is that it is produced from a site of in-betweenness: a position of power and powerlessness. As I have discussed above, the opening of the Green Line exposed Turkish Cypriot people to the Westernisation that has come to define the Greek side. This exposure has led to a collective inferiority complex amongst Turkish Cypriot people, insomuch that they consider the Greek side to be more economically advanced. Accordingly, it is through the positioning of Self in relation to two constitutive Others (mainland Turks and Greek Cypriots) that Turkish Cypriots discover themselves to be "not so European, not so Western": not equal to the Greek Cypriot Other, but not equal to the mainland Turk Other either. The participants' exclusion and ostracization of mainland Turks - their insistence on difference (Cypriotness) and their disregard of similarities shared by Turkish Cypriots and mainland Turks (Turkishness) - should thus be understood as a discursive strategy that they build on the way to asserting their cultural supremacy.

My findings concur with other studies (Hatay, 2009) insomuch that there was a tendency among my participants to blame the difference between the north and the south part of the island on the immigrants (mainland Turks) who, for them, "had made the north into 'the East'” (Hatay, 2009, p. 158). However, based on my data, I argue that the driving force behind the feeling of inferiority that emerged after the opening of the Green Line is not necessarily that the changes brought by mainland Turks to Northern Cyprus are considered to be decivilising. Rather, underlying this narrative of inferiority is also the difference of Turkishness, which is always already a part of Turkish Cypriot identity, positioning Turkish Cypriots and Greek Cypriots as "both the same and different" (Hall, 1990, p. 227). Within this complex positioning, the discourse that Northern Cyprus is becoming like Turkey, or that Turkish Cypriots are losing their Cypriotness, reflects the participants' struggle to come to terms with the ambivalence of their identity (a struggle that I refer to as "not so Eastern, not so European") and the multiplicity of feelings that come with it. I am not arguing here against the idea that identities are constantly in process and are "a matter of 'becoming' as well as of 'being'" (Hall, 1990, p. 225). However, what I propose is that as much as the participants' anxieties about assimilation into Turkish culture reflect a resistance to this sense of becoming tied to the present, lived expe- rience is also a matter of being that is connected to the colonial past and the after-effects of British colonialism. This is the trauma of post-postcoloniality.

\section{Conclusion}

Given the paucity of existing academic research, this study has developed a post-postcolonial approach to explore Turkish Cypriot cultural festivals and their relationship to wider shifts of cultural identification (i.e., with Cypriotness), with a specific focus on the post-war generation. In doing so, my work has sought to contribute to the current debates on identity politics in Northern Cyprus, as well as contributing to discussions in postcolonial studies. Drawing attention to the value of Turkish Cypriot cultural festivals, this research has also revealed how Turkish Cypriot cultural festivals, as a form of public art, can encourage multicultural tolerance in Cyprus. It became apparent that the cultural exchanges that take place at cultural festivals could prove valuable in promoting long-term inclusion and coexistence in Cyprus, where people of different backgrounds (religion, language, culture, ethnicity) live side by side. However, as my findings also suggest, the deeply ingrained political, socio-economic, and cultural residues of colonial legacies still play a salient and significant role in the ways in which differences are repositioned, and inclusions and exclusions are generated in Turkish Cypriot society. Indeed, xenophobia and racism "are among the modalities in which we can see colonialism at work" (Santos, 2016, p. 18) in Northern Cyprus.

My research has elucidated that the increasing interest in Turkish Cypriot cultural festivals is intimately tied to the issue of the East/West division, and to the way in which Turkish Cypriots position themselves in relation to Greek Cypriots and mainland Turks. More significantly, this interest reflects Turkish Cypriots' desired integration with Western society. As the examples have shown, Turkish Cypriot folk arts and cultural practices are interlinked with a new cultural movement and a new discourse of Cypriotness - which can be seen as an "alternative formation of the global" (Bhambra \& Santos, 2017, p. 3)-that is opposed to official discourse. Cultural festivals thus have at least two functions: (a) to construct and remake cultural distinctions between the Self (Turkish Cypriots) and mainland Turks and (b) to bridge difference between the Self and Greek Cypriots. Turkish Cypriots seek to close the gap between the Self and the imaginary Western Other (Greek Cypriots) and to distance themselves from the imaginary Eastern Other (mainland Turks), as a way of maintaining their sense of power (Cypriotness). The discourse of Cypriotness, as well as Turkish Cypriot folk arts, therefore, is characterised by one culture seeking to obfuscate its own vernacular hybridities and mixing, and to position itself as superior or at times equal to other cultural formations. Accordingly, the patterns and practices of inclusion and exclusion should be seen 
as the essentialisation of a version of the rational subject that is caught between a sense of Turkishness (which for Turkish Cypriots represents Easternness/ non-Europeanness) and a sense of Cypriotness (which represents Europeanness/Westernness).

\section{Acknowledgments}

I would like to thank everyone who took part in this project. I would also like to add a special thanks to the anonymous reviewers of this article for their constructive comments and suggestions.

\section{Conflict of Interests}

The author declares no conflict of interests.

\section{References}

Aydın, E. (2006). Milliyetçilik (Türkiye'nin Çıkmazı) [Nationalism (Turkey's impasse)]. Kırmızı Yayınları.

Baldini, A. (2014). Public art: A critical approach [Unpublished doctoral thesis]. Temple University.

Bazeley, P. (2013). Qualitative data analysis: Practical strategies, SAGE.

Beyazoglu, I. (2017). Nostalgia, myth, nationalism: The postcolonial nostalgia for "British" Cyprus. Revista de Cercetare si Interventie Sociala, 58, 209-220.

Bhabha, H. (1983). The other question: Stereotype, discrimination and the discourse of colonialism. Screen, 24(6), 18-36.

Bhambra, G., \& Santos, B. (2017). Introduction: Global challenges for sociology. Sociology, 51(1), 3-10.

Bilingual dictionary reflects Cypriots' common words and memories, authors say. (2016, July 3). Cyprus News Agency. https://cyprus-mail.com/2016/07/03/ bilingual-dictionary-reflects-cypriots-commonwords-memories-authors-say

Bourdieu, P. (1984). Distinction: A social critique of the judgement of taste. Routledge.

Bryant, R., \& Yakinthou, C. (2012). Cypriot perceptions of Turkey. Turkish Economic and Social Studies Foundation. TESEV.

Bryman, A. (2016). Social research methods.

Finkelpearl, T. (2013). What we made: Conversations on art and social cooperation. Duke University Press.

Habermas, J. (1989). The structural transformation of the public sphere: An inquiry into a category of bourgeois society. MIT Press.

Hadjipieris, I., \& Kabatas, O. (2017). Kibris Turk ve Rum Diyalektlerinin Ortak Sozlugu [The joint dictionary of Greek Cypriot and Turkish Cypriot dialect]. Isik Kitabevi.

Hall, S. (1990). Cultural identity and diaspora. In J. Rutherford (Ed.), Identity: Community, culture, difference (pp. 222-237). Lawrence \& Wishart.

Hall, S. (1996). Introduction: Who needs identity? In S. Hall \& P. du Gay (Eds.), Questions of cultural identity (pp. 1-17). SAGE.

Hall, S. (1997). Representation: Cultural representations and signifying practices. SAGE.

Hall, S. (2007). Living with difference: Interview with Bill Schwarz. Soundings, 37, 148-158.

Hall, S., \& Massey, D. (2010). Interpreting the crisis. Soundings, 44, 57-71.

Hatay, M. (2007). Is the Turkish Cypriot population shrinking? An overview of the ethno-demography of Cyprus in the light of the preliminary results of the 2006 Turkish-Cypriot census. PRIO Centre Reports.

Hatay, M. (2009). The problem of pigeons: Orientalism, xenophobia and a rhetoric of the 'local' in North Cyprus. The Cyprus Review, 20(2), 145-171.

Hatay, M., \& Bryant, R. (2008). The jasmine, scent of Nicosia: Of returns, revolutions, and the longing for forbidden pasts. Journal of Modern Greek Studies, 26(2), 423-449.

Kester, G. (2011). The one and the many: Contemporary collaborative art in a global context. Duke University Press.

Kizilyurek, N. (1999). Milliyetçilik Kıskacında Kıbrıs [Cyprus in the grip of nationalism]. Iletişim Yayınları.

Kizilyurek, N. (2002). Milliyetcilik Kiskacinda Kibris [Cyprus in the grip of nationalism]. Iletisim.

Kizilyurek, N. (2018). Kayip Ozne: Aslinda Hepimiz Melankoligiz [Missing subject: Actually, we are all melancholic]. Soylem Matbaa.

Knight, C. K. (2008). Public art: Theory, practice and populism. Blackwell.

Kvale, S., \& Brinkmann, S. (2009). InterViews: Learning the craft of qualitative research interviewing. SAGE.

Lacher, H., \& Kaymak, E. (2005). Transforming identities: Beyond the politics of non-settlement in North Cyprus. Mediterranean Politics, 10(2), 147-166.

Lacy, S. (Ed.). (1995). Mapping the terrain: New genre public art. Bay Press.

Lee, R. M. (1993). Doing research on sensitive topics. SAGE.

Loizides, G. N. (2007). Ethnic nationalism and adaptation in Cyprus. International Studies Perspectives, 8(2), 172-189.

Mbembe, A. (2008, January 9). What is postcolonial thinking? An interview with Achille Mbembe. Eurozine Review. https://www.eurozine.com/whatis-postcolonial-thinking

Navaro-Yashin, Y. (2006). De-ethnicizing the ethnography of Cyprus. In Y. Papadakis, N. Peristianis, \& G. Welz (Eds.), Divided Cyprus: Modernity, history, and an island in conflict (pp. 84-99). Indiana University Press.

Nevzat, A. (2005). Nationalism amongst the Turks of Cyprus: The first wave [Unpublished doctoral thesis]. University of Oulu.

Papadakis, Y. (2008). History education in divided Cyprus: A comparison of Greek Cypriot and Turkish Cypriot schoolbooks on the history of Cyprus. PRIO Centre Reports. 
Pollis, A. (1996). The social construction of ethnicity and nationality: The case of Cyprus. Nationalism and Ethnic Politics, 2, 67-90.

Pollis, A. (1998). The role of foreign powers in structuring ethnicity and ethnic conflict in Cyprus. In V. Calotychos (Ed.), Cyprus and its people: Nation, identity and experience in an unimaginable community, 1955-1997 (pp. 85-102). Westview Press.

Rhys-Taylor, A. (2013). Disgust and distinction: The case of the jellied eel. The Sociological Review, 61(2), 227-246.

Rutherford, J. (1990). The third space. Interview with Homi Bhabha. In H. G. Ders (Ed.), Identity: Community, culture, difference (pp. 207-221). Lawrence \& Wishart.

Sadikoglu, R. (2019). Cypriotness after postcolonialism [Unpublished doctoral thesis]. Goldsmiths College.

Said, E. (1993). Culture and imperialism. Vintage.

Said, E. (2005). The myth of the 'clash of civilizations' [Speech transcript]. Media Education Foundation. https://www.mediaed.org/transcripts/edwardsaid-the-myth-of-clash-civilizations-transcript.pdf (Original work published 1998)

Said, E. (2006). Orientalism: Western conceptions of the Orient. Penguin Books. (Original work published 1978)

\section{About the Author}

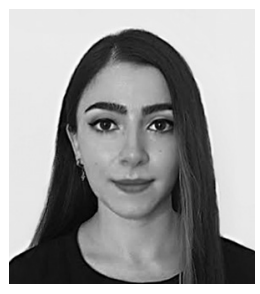

Rahme Sadikoglu received her PhD in sociology from Goldsmiths College, University of London, in 2019. Her PhD focused on the complexities involved in the contemporary fabrication of Cypriotness in Northern Cyprus. She is currently an associate lecturer in the Sociology Department at Goldsmiths College. Her research interests include the politics of Turkish Cypriot identity, with a specific emphasis on the post-war generation. This interest extends to examining how Turkish Cypriots, Greek Cypriots, and mainland Turks negotiate difference in Cyprus.
Santos, B. (2016). Epistemologies of the South and the future. From the European South: A Transdisciplinary Journal of Postcolonial Humanities, 1, 17-29.

Smith, H. (2018, January 6). "We're not Muslims enough" fear Turkish Cypriots as poll looms. The Guardian. https://www.theguardian.com/world/2018/jan/06/ were-not-muslim-enough-fear-turkish-cypriots-aspoll-looms

Swartz, D. (1997). Culture and power: The sociology of Pierre Bourdieu. University of Chicago Press.

Vural, Y., \& Özuyanık, E. (2008). Redefining identity in the Turkish-Cypriot school history textbooks: A step towards a united federal Cyprus. South European Society and Politics, 13(2), 133-154.

Vural, Y., \& Rustemli, A. (2006). Identity fluctuations in the Turkish Cypriot community. Mediterranean Politics, 11(3), 329-348.

Wise, A., \& Velayutham, S. (2014). Conviviality in everyday multiculturalism: Some brief comparisons between Singapore and Sydney. European Journal of Cultural Studies, 17(4), 406-430.

Zuidervaart, L. (2011). Art in public: Politics, economics, and a democratic culture. Cambridge University Press. 